\title{
SYSTEM PIECZY ZASTĘPCZEJ W WIELKIEJ BRYTANII A POLSKIE RODZINY ZASTĘPCZE
}

\begin{abstract}
AвSTRAct. Walancik-Ryba Karolina, System pieczy zastępczej w Wielkiej Brytanii a polskie rodziny zastępcze [Foster Care System in Great Britain and Polish Foster Families]. Studia Edukacyjne nr 52, 2019, Poznań 2019, pp. 245-256. Adam Mickiewicz University Press. ISSN 1233-6688. DOI: 10.14746/ se.2019.52.16
\end{abstract}

The article "Foster care system in Great Britain and Polish foster families" is devoted to the British system of foster care, which allows to create a foster family by Polish citizens. The article discusses the main principles on which the foster care and its forms are based. National standards and requirements for candidates to foster families were presented as well as issues related to the implementation of foster care, including these regarding support for foster parents and housing or financial requirements.

Key words: foster family, foster care, foster care system in Great Britain, child

\section{Wstęp}

Od początku lat osiemdziesiątych XX wieku obserwuje się w Europie znaczący spadek liczby instytucjonalnych form pieczy zastępczej. Reformy $\mathrm{w}$ zakresie pieczy zastępczej nad dzieckiem $\mathrm{w}$ rodzinach dysfunkcjonalnych zmierzają $\mathrm{w}$ kierunku tworzenia i rozwoju rodzinnych form pieczy zastępczej, w tym głównie rodzin zastępczych ${ }^{1}$. Wiąże się to z modelem opieki nad dzieckiem, skoncentrowanym na odkrywaniu potencjału i możliwości rodziny i jej otoczenia. Założono w nim, że wyłącznie w sytuacjach kryzysowych realizowane będą formy opieki nad dzieckiem poza rodziną. W modelu tym

${ }^{1} \mathrm{~J}$. Boddy, Understanding permanence for looked after children: A review of research for the Care Inquiry, London: The Care Inquiry, https://www.thefosteringnetwork.org.uk/sites/www.fostering.net/files/resources/england/understanding-permanence-for-lac-janet-boddy.pdf, [dostęp:07.07.2019]. 
priorytetem jest wsparcie zarówno dziecka, jak i rodziny w ich naturalnym środowisku, realizowane poprzez zintensyfikowaną, profesjonalną pomoc socjalną oraz pedagogiczną.

Nowoczesne rozwiązania systemowe dotyczące pieczy nad dzieckiem pozbawionym opieki rodziców biologicznych są opracowywane między innymi przez międzynarodowe organizacje, takie jak FICE (Federation Internationale de Communautes Educatives), czy IFCO (International Foster Care Organisation). Przyjęte przez te organizacje standardy określają następujące wymogi jakościowe „opieki":

- dziecko i jego rodzina biologiczna mają prawo do wsparcia oraz interwencji ze strony systemu opieki w każdym przypadku, kiedy odczuwają potrzebę zmiany swojej aktualnej sytuacji życiowej, zawsze powinni być wysłuchani, a ich potrzeby traktowane z należnym szacunkiem, wsparcie powinno między innymi: umożliwić podjęcie najlepszej decyzji dotyczącej dalszej drogi życiowej dziecka i rodziny, przy czym podstawowym priorytetem są tu bezpieczeństwo i potrzeby dziecka, dziecko ma prawo do uczestniczenia w decyzjach dotyczących jego losów;

- prawdziwie profesjonalna i zmierzająca do zaspokojenia potrzeb dziecka decyzja dotycząca jego losów musi opierać się na obiektywnej ocenie i wyborze rozwiązania najlepszego dla dziecka, bez żadnych uprzedzeń i doktrynalnych założeń;

- decyzja winna zakładać, że zarówno rodzina biologiczna, adopcyjna, zastępcza, jak i specjalistyczna placówka mogą być najlepszym rozwiązaniem dla specyficznych, indywidualnych potrzeb dziecka;

- w opiece poza rodziną biologiczną winna obowiązywać zasada nierozdzielania rodzeństwa;

- proces przenoszenia dziecka do nowego środowiska powinien być doskonale przygotowany i zaplanowany oraz odbywać się stopniowo z uwzględnieniem wrażliwości dziecka i najlepszych możliwości jego rozwoju; taki plan powinien ewoluować, aby można było osiągnąć najlepsze efekty $\mathrm{w}$ procesie rozwoju dziecka;

- rodzina lub placówka, w której przebywa dziecko poza domem rodzinnym musi odpowiadać jego potrzebom i sytuacji życiowej, dziecko musi wzrastać w środowisku wspierającym, chroniącym je i umożliwiającym rozwój;

- dziecko musi mieć zarówno szanse na podtrzymanie bezpiecznego kontaktu ze swoim środowiskiem pochodzenia, jak i na budowę stabilnych relacji z nowym opiekunem².

${ }^{2}$ Quality4Children Quality Standards in Out-Of-Home Child Care in Europe, https:/ / www.sos-childrensvillages.org/getmedia/67a4237f-3456-4fa9-b6e9-e954075cadd0/QC_colour_2.pdf, s. 14, [dostęp: 07.07.2019]. 
Celem artykułu jest próba prezentacji problematyki systemu pieczy zastępczej w Wielkiej Brytanii w kontekście możliwości utworzenia rodziny zastępczej przez zamieszkałych tam polskich obywateli.

\section{System opieki nad dzieckiem w Wielkiej Brytanii}

System opieki nad dzieckiem w Wielkiej Brytanii jest bardzo zaawansowany $^{3}$. Od XVII wieku rozwój opieki w tym kraju jest ciągły. System opieki i przeciwdziałania przemocy nad dzieckiem nazywany jest Child Care (Ochrona Dziecka). Na system ten składają się instytucje koordynowane przez Okręgowy Komitet Ochrony Dziecka. Istotną rolę w ochronie dziecka pełnią ponadto władze samorządowe poprzez Wydział Usług Społecznych", w którym zatrudnieni są pracownicy socjalni i terapeuci. Obowiązkiem tych osób jest pełnienie całodobowych dyżurów w celu badania wszelkich przejawów przemocy w stosunku do dziecka.

Kwestie związane $\mathrm{z}$ ingerencją sądów we władzę rodzicielską oraz rodzinną pieczę zastępczą regulują Children Act 1989 oraz Children Act 2004. W tym drugim podkreślono, że pierwszymi i podstawowymi wychowawcami dziecka są rodzice, którzy powinni mieć autonomię wychowawczą. Ponadto, każdy obywatel ma obowiązek powiadamiania odpowiednich organów o każdej znanej czy nawet domniemanej sytuacji krzywdzącej dziecko. Również ono samo ma prawo domagać się pomocy. W sytuacji zagrożenia dobra dziecka zwoływane jest tak zwane zebranie w sprawie jego ochrony z udziałem dziecka, przedstawicieli wszystkich instytucji zaangażowanych w pracę z dzieckiem i rodzicami, na którym dokonuje się oceny sytuacji dziecka i uzgadnia plan jego ochrony ${ }^{6}$. Według Centrum Prawnego Dziecka, plan ochrony dziecka powinien:

- określać prawdopodobieństwo, że dziecku stanie się krzywda i poszukiwać sposobów, które zapewnią mu odpowiednią ochronę;

${ }^{3}$ Zob. Report Understanding the lives of care-experienced young people in Denmark, England and Norway - A cross-national documentary review, VIVE - Viden til Velfærd 2019, https:/ / pure.vive.dk/ws/files/2377195/100442_Understanding_the_lives_of_care_experienced_young_people.pd, s. 22, [dostęp: 06.07.2019].

${ }^{4}$ C. Warren-Adamson (red.), Family Centres and their International Role in Social Action: Social Work as Informal Education, 1 edition, 5 October 2017, Routledge, s. 5; J. Parkin, Ochrona dziecka w Zjednoczonym Królestwie, Materiały z konferencji: Dzieci i młodzież jako ofiary przemocy, Gdańsk 1997, s. 2.

${ }^{5}$ J. Gorczowska, Znaczenie diagnozy, szkoleń i systemu wsparcia opiekunów w utrzymaniu stabilności pieczy zastępczej. Rodziny zastępcze z pomoca rodzinom biologicznym, Kwartalnik Pedagogiczny, 2012, 3(225), s. 84.

${ }^{6}$ M. Ruszkowska, Rodzina zastępcza jako środowisko opiekuńczo-wychowawcze, Centrum Rozwoju Zasobów Ludzkich, Warszawa 2013, s. 56. 
- określać krótko- i długofalowe cele mające zmniejszyć ryzyko wyrządzenia krzywdy dziecku oraz chronić jego dobro;

- określać zakres odpowiedzialności poszczególnych osób oraz konkretne działania;

- przedstawiać sposoby monitorowania i oceny postępów ${ }^{7}$.

W Wielkiej Brytanii opracowano ponadto program Every Child Matters (Każde Dziecko Jest Ważne) do wdrożenia koniecznych zmian do istniejącego już systemu opieki. Jednym z celów tego programu jest opracowanie krajowych ram koncentrujących się na poprawie ładu, ustaleniu i zwiększeniu poczucia odpowiedzialności oraz możliwości działania we wszystkich sektorach, które są odpowiedzialne za dobro dzieci. Dziesięć kluczowych elementów ram krajowych obejmuje:

- obowiązek współpracy na rzecz promowania dobra dzieci oraz młodzieży;

- obowiązek dokonywania ustaleń mających na celu zabezpieczenie oraz promowanie dobra dzieci i młodzieży;

- rozwój ustawowych lokalnych rad ochrony dzieci (LSCB), które mają zastąpić nieustawowe miejscowe komitety ochrony dzieci (ACPC);

- powołanie lokalnych dyrektorów do spraw usług dla dzieci;

- Narodowe Ramy Usług dla Dzieci, Młodzieży oraz związanych z Macierzyństwem

- ramy wyników;

- opracowanie zintegrowanych ram inspekcji;

- powołanie Komisarza do spraw Dzieci;

- opracowanie Wspólnych Ram Oceny;

- reformę mającą na celu rozwój umiejętności oraz zapewnienie odpowiedniej kadry ${ }^{8}$.

Główną zasadą organizowania „opieki na dzieckiem” w Wielkiej Brytanii jest najszybszy powrót dziecka do rodziny biologicznej albo zapewnienie mu innego środowiska rodzinnego. Jednocześnie, formy instytucjonalne są systematycznie ograniczane na rzecz form rodzinnych. Ponadto, formy instytucjonalne przybierają formę małych placówek o charakterze terapeutycznym, a placówki publiczne są zastępowane prywatnymi. Dzieci umieszczane są bądź w opiece rodzinnej (rodziny zastępcze), bądź zakładowej (domy dzie-

${ }^{7}$ HM Government, Working Together to Safeguard Children, Crown copyright 2018, https://assets.publishing.service.gov.uk/government/uploads/system/uploads/attachment_ data/file/779401/Working_Together_to_Safeguard-Children.pdf, [dostęp: 09.07.2019].

${ }^{8}$ M. Titterton, S. Pelling-Deeves, P. Nolan (online), Ustugi $i$ instytucje opieki społecznej w Wielkiej Brytanii, Ekspertyza, CRZL, WRZOS, OSPiMOPS „Centrum”, SSOPS FORUM, Warszawa, http:/ / www.wrzos.org.pl/projekt1.18/download/Ekspertyza\%20Anglia.pdf, [dostęp: 06.07.2019]. 
cięce, domy władz lokalnych, domy prowadzone przez organizacje pozarządowe, prywatne, rejestrowane domy opieki, przedszkolne hostele).

Podkreślić należy, że w przypadku dzieci z domów dziecka opracowywane oraz wdrażane są plany opieki zgodnie z konkretnymi potrzebami każdego dziecka, które ma pracownika odpowiedzialnego za nadzorowanie opieki nad nim. Ponadto, dzieci mieszkające $w$ domach otrzymują wsparcie $w$ tworzeniu oraz utrzymywaniu relacji społecznych, uczestniczeniu $\mathrm{w}$ formach spędzania wolnego czasu oraz wydarzeniach towarzyskich, czy też dbałości o zdrowie i edukację. Dzieci mieszkające w domach dziecka mają także odpowiednio opracowane programy „opieki nad odejściem”, które mogą określać pomoc, jakiej będą potrzebować aby żyć samodzielnie i jak taka pomoc będzie im świadczona. Do każdego dziecka przypisany jest Niezależny Pracownik Oceny. Taka osoba odgrywa kluczową rolę w zapewnieniu stabilności umieszczenia dziecka w danym miejscu?

Państwo nakłada również na władze obowiązek opieki na osobami młodymi, które osiągnęły pełnoletniość, do ukończenia dwudziestego pierwszego roku życia w postaci: doradztwa, wsparcia finansowego i emocjonalnego ${ }^{10}$.

Liczba dzieci objętych "opieką" (tzw. Looking after, włącznie z adopcją) rośnie systematycznie przez ostatnie dziesięć lat i dane wskazują, że na 31 marca 2018 roku pieczą zastępczą objęto 75420 młodych, to jest o $4 \%$ więcej niż w 2017 roku $^{11}$.

W Wielkiej Brytanii wyróżnia się następujące typy pieczy zastępczej: pilną (emergency) - opieka w nagłych wypadkach trwająca zwykle kilka dni; krótkoterminową (short-term) - dziecko może pozostawać w opiece krótkoterminowej do kilku miesięcy; długoterminową (long-term) - może trwać kilka lat lub do osiągnięcia dorosłości przez dziecko; specjalistyczną (special) - kiedy wymagane jest szczególne zaangażowanie, na przykład dla dzieci niepełnosprawnych.

Funkcjonuje także opieka chwilowa (short-breaks) polegająca na wspomaganiu rodziców biologicznych, często w przypadku dzieci chorych, upośledzonych, która trwa od kilku godzin do tygodnia w miesiącu; opieka dla

9 Tamże.

${ }^{10}$ K. Płowiec, Pomoc bezdomnej młodzieży w Wielkiej Brytanii, Problemy Opiekuńczo-Wychowawcze, 2004, 5, s. 42.

${ }^{11}$ Children Looked After in England Including Adoption: 2017 to 2018. Local Authority Tables (2018), Department for Education, Crown Copyright 2018, https://assets.publishing. service.gov.uk/government/uploads/system/uploads/attachment_data/file/757922/Children_looked_after_in_England_2018_Text_revised.pdf, s. 1, (dostęp: 06.07.2019], Foster care in England - Parliament UK, DEBATE PACK, Number CDP-0064 12, March 2018, https:/ / www. parliament.uk/commons-library,pdf, s. 4, [dostęp: 07.07.2019], TACT Briefing Foster Care in England A Review for the Department of Education, December 2017, https://www.tactcare. org.uk/content/uploads/2018/02/TACT-Briefing-Foster-Care-in-England.pdf, s. 2, [dostęp: 09.07.2019]. 
nieletnich przestępców (remand); opieka preadopcyjna (fostering fot adoption); tzw. Family and friends or Kinship Care, gdzie dzieckiem opiekuje się lokalna rada, dziecko mieszka z osobą którą zna, zwykle członkiem rodziny; instytucja specjalisty terapeutycznego (specialist therapeutic) dla dzieci o złożonych potrzebach lub trudnych zachowaniach; opieka dla młodych matek ${ }^{12}$.

Zaznaczyć należy, że rodziny zastępcze traktuje się w Wielkiej Brytanii docelowo jako najwłaściwszą formę opieki nad dziećmi umieszczonymi poza rodziną naturalną ${ }^{13}$. W ramach rodzin zastępczych można wyróżnić: rodziny zastępcze, gdzie rodzicami zastępczymi są pracownicy instytucji lokalnych społeczności, rodziny zastępcze spokrewnione oraz rodziny zastępcze, gdzie rodzicem jest osoba, z którą dziecko mieszka od przynajmniej 3 lat. Kontrolą oraz kwalifikacją rodzin zastępczych zajmują się władze lokalne poprzez swoje instytucje ${ }^{14}$.

Wskazać należy, że rodzina zastępcza funkcjonująca w Wielkiej Brytanii od jej ustanowienia rozwija się i ewoluuje - od opieki nad małymi dziećmi do opieki na dziećmi trudnymi lub niepełnosprawnymi. Osiąganie stopnia specjalizacji uzależnione jest oczywiście od liczby przebytych szkoleń. Warto również wskazać, że każde dziecko umieszczone w rodzinie zastępczej ma swojego opiekuna socjalnego, który sporządza plan wychowawczy dla dziecka i monitoruje jego wykonanie. Ponadto, w Wielkiej Brytanii istnieją rodziny pomocowe, których zadaniem jest odciążenie rodziców zastępczych w sprawowanych przez nich obowiązkach przez krótki okres.

Należy podkreślić, że w omawianym systemie pieczy zastępczej priorytetowo traktowane są zarówno dzieci, jak i ich rodziny naturalne. Powszechne są lokalne Ośrodki Rodziny, które oferują programy wspierania rodziny w celu poprawy jej funkcjonowania ${ }^{15}$.

\section{Polskie rodziny zastępcze w Wielkiej Brytanii - wymogi dla kandydatów, prawa i obowiązki}

Wielka Brytania jest jednym z krajów, w którym w ostatnich 10 latach osiedliło się najwięcej Polaków. Według oficjalnych brytyjskich statystyk, pod koniec 2016 roku liczba polskich obywateli zamieszkujących w Wielkiej

${ }^{12}$ Foster carers. Types of Foster care, https://www.gov.uk/foster-carers/types-of-fostercare, [dostęp: 05.07.2019].

${ }^{13}$ A. Kula, J. Jarosz, Systemowe rozwiązanie opieki nad dziećmi w Zjednoczonym Królestwie, [w:] System opieki kompensacyjnej w zjednoczonej Europie, red. S. Badora, D. Marzec, Kraków 2002, s. 447.

${ }^{14}$ Tamże, s. 441.

${ }^{15}$ M. Ruszkowska, Rodzina zastępcza jako środowisko opiekuńczo-wychowawcze, Warszawa 2013, s. 57. 
Brytanii przekroczyła 1 milion, a dzieci, których jeden z rodziców urodził się w Polsce, urodziło się ponad 22 tysiące. Wśród Polaków mieszkających w Wielkiej Brytanii około 220 tysięcy to dzieci i młodzież poniżej 18. roku życia ${ }^{16}$. Należy wskazać, że 28,4\% dzieci urodzonych w 2017 roku w Wielkiej Brytanii to dzieci matek pochodzących spoza tego kraju. To najwyższy wynik w tej kategorii od 1969 roku, kiedy zaczęto prowadzić taką statystykę. W 2017 roku urodziło się w Wielkiej Brytanii 486417 dzieci, których matki pochodzą z tego kraju i 192 651, których matki urodziły się za granicą. Prym w tej kategorii wiodą Polki, które stanowią 10,8\% zagranicznych matek. Polki urodziły w Wielkiej Brytanii 20779 dzieci ${ }^{17}$.

Niestety, liczba interwencji w rodzinach polskich emigrantów w Wielkiej Brytanii jest wysoka. Do sierpnia 2017 roku do rodzin zastępczych trafiło 115 polskich dzieci, a w całym 2016 roku - 252. To rekord na tle innych państw

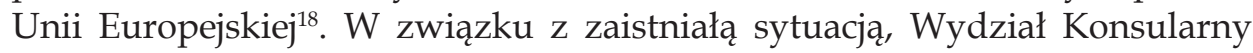
Ambasady RP w Londynie, wspólnie z Konsulatem Generalnym RP w Manchesterze, Konsulatem Generalnym RP w Edynburgu oraz Konsulatem Generalnym RP w Belfaście, wystosował apel zachęcający Polaków do podejmowania roli rodziców zastępczych w Wielkiej Brytanii.

$\mathrm{Na}$ specjalnie stworzonych do tej akcji stronach internetowych podano szczegółowe informacje dotyczące możliwości ustanowienia „polskiej rodziny zastępczej" w Wielkiej Brytanii.

Rekrutacją „polskich rodzin zastępczych” zajmują się w Wielkiej Brytanii władze lokalne. System jest oparty na wywiadach, rozmowach i szkoleniu oraz zbieraniu opinii środowiskowych, a także na analizie dostarczonych dokumentów. Kandydaci muszą spełniać odpowiednie wymogi, czyli takie jak: niekaralność, wiek kandydata co do zasady powyżej 21 lat (należy wskazać, że urzędy lokalne mają różne warunki dotyczące wymaganego wieku), odpowiednie warunki mieszkaniowe: oddzielny pokój dla dziecka (mieszkanie/ dom nie musi być własnością, może być wynajmowane). Istotnym wymogiem jest też znajomość języka angielskiego w stopniu umożliwiającym kontakt w sprawach życia codziennego z pracownikami służb socjalnych oraz uczestnictwo w wymaganych szkoleniach. Jako wymóg wskazano również takie cechy, jak: otwartość, umiejętność budowania relacji i współpracy, empatia, cierpliwość i zaangażowanie w powierzoną rolę. Bardzo ważnym wy-

${ }^{16}$ I ty możesz być rodzina zastępczą w Wielkiej Brytanii, https://londyn.msz.gov.pl/pl/informacje_konsularne/rodzinzastepcza/, [dostęp: 05.07.2019].

${ }_{17}$ Zob. Office for National Statistics, https://www.ons.gov.uk/, [dostęp: 05.07.2019].

${ }^{18}$ I. Kacprzak, Wielka Brytania: Polskie rodziny traca dzieci, https://www.rp.pl/Spoleczenstwo/308069963-Wielka-Brytania-Polskie-rodziny-traca-dzieci.html, [dostęp: 06.07.2019]; I. Kadłuczka, Stużby socjalne Wielkiej Brytanii rocznie odbieraja Polakom aż setke dzieci, http:/ / wyborcza. pl/1,75398,13648936,Sluzby_socjalne_Wielkiej_Brytanii_rocznie_odbieraja.html?disableRedirects=true, [dostęp: 06.07.2019]. 
mogiem jest także zrozumienie aspektów różnorodności kulturowej. Należy podkreślić, że stan cywilny, wykształcenie, czy kwalifikacje zawodowe nie mają wpływu na proces rekrutacji.

Osoby zainteresowane rodzicielstwem zastępczym mogą wyszukać właściwy urząd prowadzący rekrutację na dedykowanej stronie internetowej ${ }^{19}$. Lokalne władze na swoich stronach internetowych zamieszczają szczegółowe informatory odnośnie procedury rekrutacji rodzin zastępczych, informacje dotyczące wsparcia finansowego, psychologicznego i poradnictwa rodzinnego dla opiekunów zastępczych. Urzędy lokalne organizują również cykliczne, otwarte spotkania informacyjne ${ }^{20}$. Poza wymaganymi dokumentami kandydaci mają obowiązek wziąć udział w warsztatach psychoedukacyjnych. Mogą skorzystać również całodobowo z porad specjalistów związanych z przyjęciem roli rodzica zastępczego zarówno osobiście, jak i w formie telefonicznej ${ }^{21}$. W ramach procedury ma miejsce również wizyta pracownika socjalnego w miejscu zamieszkania kandydatów, którego zadaniem jest ocena warunków mieszkaniowych i przeprowadzenie wywiadu środowiskowego, a także dokonanie ustaleń w instytucjach zewnętrznych odnośnie między innymi karalności, stanu zdrowia. Proces rekrutacji trwa około 6-8 miesięcy.

O umieszczeniu dziecka w rodzinie zastępczej oraz o długości okresu pieczy zastępczej rozstrzyga sąd. Rodzice zastępczy przejmują opiekę tymczasowo, na różny czas, uwarunkowany indywidualną sytuacją dziecka i rodziców. Istotne jest, że do rodziny zastępczej mogą być również skierowane dzieci innej narodowości. Przy umieszczaniu dziecka w rodzinie zastępczej znaczenie ma również wiek dziecka (powierza się dziecko od trzech do czterech lat młodsze od najmłodszego dziecka w rodzinie), a liczba dzieci powinna być jak najmniejsza (nie umieszcza się w jednej rodzinie więcej niż troje dzieci, wyjątek stanowią rodzeństwa).

Na utrzymanie dziecka przekazywane są fundusze (weekly fostering allowance), których wysokość jest zależna od wieku dziecka i danej gminy. Na przykład, w Londynie zasiłek ten wynosi 144 GBP/tydzień w przypadku niemowląt i rośnie aż do 219 GBP/tydzień w przypadku małoletnich w wieku 16-17 lat. W pozostałych częściach Wielkiej Brytanii kwoty te wynoszą odpowiednio od 125 GBP do 188 GBP tygodniowo. Osoby sprawujące opiekę

${ }_{19}$ Zob. Apply to foster a child through your council, https://www.gov.uk/apply-foster-childcouncil, [dostęp: 06.07.2019].

${ }^{20}$ Zob. Camdem, Welcome to your council, https://www.camden.gov.uk/ccm/content/ social-care-and-health/services-forchildren-and-families/fostering-and-adoption/could-you-foster/, [dostęp: 06.07.2019]; HSC. Adoption\&Foster Care, http:/ /www.adoptionandfostering. hscni.net/fostering (Irlandia Północna), [dostęp: 06.07.2019].

${ }^{21}$ Zob. About Fosterline, http://www.fosterline.info/, [dostęp: 07.07.2019]. 
mają także prawo do specjalnych dodatków i ulg podatkowych ${ }^{22}$. Istnieje stałe zwolnienie z podatku do 10000 GBP rocznie (mniej, jeśli piecza sprawowana jest przez krótszy okres), które jest dzielone równo pomiędzy wszystkich opiekunów zastępczych w tym samym gospodarstwie domowym. Oznacza to, że nie trzeba płacić podatku od pierwszego dochodu z pieczy zastępczej w wysokości 10000 GBP. Ulga podatkowa przysługuje na każdy tydzień (lub część tygodnia), w której dziecko przebywa w pieczy zastępczej. Należy podkreślić, że rodzicom zastępczym nie przysługuje ustawowe prawo do urlopu w celu opieki nad dziećmi zastępczymi ${ }^{23}$.

Każdej rodzinie zastępczej przydzielany jest superwizujący pracownik socjalny (Supervising Social Worker), który jest w stałym kontakcie z rodziną zastępczą i po umieszczeniu dziecka w rodzinie zastępczej ma obowiązek odwiedzać ją co cztery tygodnie w ramach wizyt superwizyjnych. Jeżeli istnieje taka potrzeba, wizyty te mogą być częstsze ${ }^{24}$. Rodzina zastępcza może również uzyskać wsparcie specjalistów w zakresie informacji dotyczących przysługujących jej praw i obowiązków ${ }^{25}$.

Opisana inicjatywa zachęcająca do utworzenia rodziny zastępczej przez obywateli polskich, w obliczu masowej emigracji Polaków do Wielkiej Brytanii, wydaje się rozwiązaniem bardzo istotnym i potrzebnym. Warto wspomnieć również o AG Family Support, czy Polskiej Niezależnej Agencji Rodzin Zastępczych - Polish Independent Fostering Agency PIFA, w której polscy pracownicy socjalni pomagają przejść przez procedurę i zapewniają wsparcie podczas opieki nad dziećmi.

\section{Podsumowanie}

Pomimo ukazujących się w prasie artykułów dotyczących „bezprawnego odebrania dzieci Polakom", istniejący w Wielkiej Brytanii system pieczy zastępczej należy uznać za prorodzinny. W kraju tym zlikwidowano bowiem już wiele ośrodków stałego pobytu, a zastąpiono je intensywną pomocą so-

${ }^{22}$ Foster carers. Types of Foster care, https://www.gov.uk/foster-carers/types-of-foster-care, [dostęp: 05.07.2019]; zob. także A. Kula, J. Jarosz, Systemowe rozwiązanie opieki nad dziećmi, s. 422.

${ }^{23}$ Foster carers/help with the cost of fostering, https://www.gov.uk/foster-carers/help-with-the-cost-of-fostering, [dostęp: 06.07.2019]; Foster carers/claiming benefits while fostering, https://www.gov.uk/foster-carers/claiming-benefits-while-fostering, [dostęp: 06.07.2019].

${ }^{24}$ J. Gorczowska, Znaczenie diagnozy, szkoleń i systemu wsparcia opiekunów w utrzymaniu stabilności pieczy zastępczej. Rodziny zastępcze z pomoca rodzinom biologicznym, Kwartalnik Pedagogiczny, 2012, 3(225), s. 94.

${ }^{25}$ Zob. Foster carers/training and support for foster carers, https://www.gov.uk/foster-carers/training-and-support-for-foster-carers, [dostęp: 06.07.2019]; M. Titterton, S. Pelling-Deeves, P. Nolan (online), Usługi i instytucje opieki społecznej w Wielkiej Brytanii. 
cjalno-pedagogiczną w rodzinach. Cechą charakterystyczną tego systemu jest również tendencja do tworzenia małych form na wzór rodziny naturalnej, a przede wszystkim subsydiarność pieczy zastępczej wobec relacji naturalnych $^{26}$. Ponadto, za najkorzystniejszy uważa się pobyt w krótkoterminowej profesjonalnej rodzinie zastępczej, z jednoczesnym akcentowaniem konieczności powrotu dziecka do rodziny naturalnej.

Brytyjski system pieczy zastępczej nad dzieckiem cechuje elastyczność. Cecha ta wynika zarówno z konieczności doboru pieczy do różnych potrzeb dziecka znajdującego się w konkretnej sytuacji, jak i aktualnych uwarunkowań politycznych, geograficznych i kulturowych. Elastyczność polega, w szczególności, na działaniu mającym na celu ustalenie przez pracowników socjalnych sytuacji życiowej i potrzeb dziecka w każdym konkretnym przypadku indywidualnie ${ }^{27}$, a następnie wyborze najbardziej odpowiedniej formy pieczy zastępczej.

Istotną zasadą brytyjskiego systemu jest zasada planowania stałości pieczy zastępczej ${ }^{28}$, która ma zapobiegać nadużyciom i nieuzasadnionemu umieszczaniu dziecka poza rodziną. Nie podlega bowiem wątpliwości fakt, że jedynie stałość opieki i więzi uczuciowych daje dziecku poczucie bezpieczeństwa, które jest istotne w jego prawidłowym rozwoju ${ }^{29}$.

\section{BIBLIOGRAFIA}

About Fosterline, http://www.fosterline.info/, [dostęp: 07.07.2019].

Andrzejewski M., w: System Prawa Prywatnego, t. 12 - Prawo rodzinne i opiekuńcze, red. Smyczyński, wyd. 2, Wydawnictwo C.H. Beck, Warszawa 2011.

Apply to foster a child through your council, https:/ / www.gov.uk/apply-foster-child-council, [dostęp: 06.07.2019].

Badora S., Marzec D. (red.), System opieki kompensacyjnej w zjednoczonej Europie, Oficyna Wydawnicza Impuls, Kraków 2002.

Boddy J., Understanding permanence for looked after children: A review of research for the Care Inquiry, London: The Care Inquiry, https:// www.thefosteringnetwork.org.uk/sites/ www.fostering.net/files/resources/england/understanding-permanence-for-lac-janet-boddy.pdf, [dostęp:07.07.2019].

${ }^{26}$ M. Andrzejewski, w: System Prawa Prywatnego, t. 12 - Prawo rodzinne i opiekuńcze, red. Smyczyński, wyd. 2, Warszawa 2011, s. 421, Legalis - 1115206.

27 Fostering Services: National Minimum Standards, Department for Educatopn, Crown Copyright 2011, ISBN: 978-1-84775-8675https://assets.publishing.service.gov.uk/government/uploads/system/uploads/attachment_data/file/192705/NMS_Fostering_Services.pdf, [dostęp: 07.07.2019]; Prospective Foster Carer Report (Form F) England, Coram BAAF, https://corambaaf.org.uk/sites/default/files/electronic-forms/SAMPLE\%20Coram BAAF\%20Form\%20F\%20(England)\%202018.pdf, [dostęp: 07.07.2019].

${ }_{28}$ Tamże, s. 418.

${ }^{29}$ W. Zych, Europejskie kierunki w opiece kompensacyjnej, [w:] System opieki kompensacyjnej w zjednoczonej Europie, red. S. Badora, D. Marzec, Kraków 2002, s. 264. 
Camdem, Welcome to your council, https://www.camden.gov.uk/ccm/content/socialcare-and-health/services-forchildren-and-families/fostering-and-adoption/couldyou-foster/, [dostęp: 06.07.2019].

Children Looked After in England Including Adoption: 2017 to 2018, Local Author, https:/ / assets.publishing.service.gov.uk/government/uploads/system/uploads/attachment_data/file/757922/Children_looked_after_in_England_2018_Text_revised.pdf, s.1, [dostęp: 06.07.2019].

Find a fostering service, http://www.fosterline.info/find-a-fostering-service/, [dostęp: 06.07.2019].

Foster care in England - Parliament UK, DEBATE PACK, Number CDP-0064 12, March 2018, https:/ / www.parliament.uk/commons-library,pdf, [dostęp: 07.07.2019].

Foster carers. Types of Foster care, https://www.gov.uk/foster-carers/types-of-foster-care, [dostęp: 05.07.2019].

Foster carers/claiming benefits while fostering, https://www.gov.uk/foster-carers/claiming-benefits-while-fostering, [dostęp: 06.07.2019].

Foster carers/help with the cost of fostering, https://www.gov.uk/foster-carers/help-withthe-cost-of-fostering, [dostęp: 06.07.2019].

Foster carers/training and support for foster carers, https://www.gov.uk/foster-carers/training-and-support-for-foster-carers, [dostęp: 06.07.2019].

Fostering Services: National Minimum Standards, Department for Educatopn, Crown Copyright 2011, ISBN: 978-1-84775-8675https://assets.publishing.service.gov.uk/ government/uploads/system/uploads/attachment_data/file/192705/NMS_Fostering_Services.pdf, [dostęp: 07.07.2019].

Gorczowska J., Znaczenie diagnozy, szkoleń i systemu wsparcia opiekunów w utrzymaniu stabilności pieczy zastępczej. Rodziny zastępcze z pomoca rodzinom biologicznym, Kwartalnik Pedagogiczny, 2012, 3(225).

HM Government, Working Together to Safeguard Children, Crown copyright 2018, https:/ / assets.publishing.service.gov.uk/government/uploads/system/uploads/ attachment_data/file/779401/Working_Together_to_Safeguard-Children.pdf, [dostęp: 09.07.2019].

HSC. Adoption\&Foster Care, http://www.adoptionandfostering.hscni.net/fostering (Irlandia Północna), [dostęp: 06.07.2019].

I ty możesz być rodziną zastępczą w Wielkiej Brytanii, https:/ / londyn.msz.gov.pl/pl/informacje_konsularne/rodzinzastepcza/, [dostęp: 05.07.2019].

Kacprzak I., Wielka Brytania: Polskie rodziny traca dzieci, https:/ / www.rp.pl/Spoleczenstwo/ 308069963-Wielka-Brytania-Polskie-rodziny-traca-dzieci.html, [dostęp: 06.07.2019].

Kadłuczka I., Stużby socjalne Wielkiej Brytanii rocznie odbierają Polakom aż setkę dzieci, http:/ / wyborcza.pl/1,75398,13648936,Sluzby_socjalne_Wielkiej_Brytanii_rocznie_odbieraja. html?disableRedirects=true, [dostęp: 06.07.2019].

Kula A., Jarosz J., Systemowe rozwiąanie opieki nad dziećmi w Zjednoczonym Królestwie, [w:] System opieki kompensacyjnej w zjednoczonej Europie, red. S. Badora, D. Marzec, Oficyna Wydawnicza Impuls, Kraków 2002.

Make a difference and take your first step into fostering today!, http:/ / www.manchester.gov. uk/fostering, [dostęp: 06.07.2019].

Office for National Statistics, https:/ / www.ons.gov.uk/, [dostęp: 05.07.2019].

Parkin J., Ochrona dziecka w Zjednoczonym Królestwie, Materiały z konferencji „Dzieci i młodzież jako ofiary przemocy", Gdańsk 1997.

Płowiec K., Pomoc bezdomnej młodzieży w Wielkiej Brytanii, Problemy Opiekuńczo-Wychowawcze, 2004, 5 . 
ProspectiveFosterCarerReport(FormF) England,CoramBAAF,https:/ / corambaaf.org.uk/ sites/default/files/electronic-forms/SAMPLE $\%$ 20CoramBAAF $\% 20$ Form $\% 20 \mathrm{~F} \% 20$ (England)\%202018.pdf, [dostęp: 07.07.2019].

Quality4Children Quality Standards in Out-Of-Home Child Care in Europe, https:/ / www.sos-childrensvillages.org/getmedia/67a4237f-3456-4fa9-b6e9-e954075cadd0/ QC_colour_2.pdf, s. 14, [dostęp: 07.07.2019].

Report Understanding the lives of care-experienced young people in Denmark, England and Norway - A cross-national documentary review, VIVE - Viden til Velfærd 2019, e-ISBN: 978-87-7119-616-0, https://pure.vive.dk/ws/files/2377195/100442_ Understanding_the_lives_of_care_experienced_young_people.pdf, s. 22, [dostęp: 06.07.2019].

Ruszkowska M., Rodzina zastępcza jako środowisko opiekuńczo-wychowawcze, Centrum Rozwoju Zasobów Ludzkich, Warszawa 2013.

Smyczyński T. (red.), System Prawa Prywatnego, t. 12 - Prawo rodzinne i opiekuńcze, Wydawnictwo C.H.Beck, Warszawa 2011.

TACT Briefing Foster Care in England A Review for the Department of Education, December 2017, https://www.tactcare.org.uk/content/uploads/2018/02/TACT-BriefingFoster-Care-in-England.pdf, [dostęp: 09.07.2019].

Titterton M., Pelling-Deeves S., Nolan P. (on line), Ustugi i instytucje opieki społecznej w Wielkiej Brytanii, Ekspertyza, CRZL, WRZOS, OSPiMOPS „Centrum”, SSOPS FORUM, Warszawa, http://www.wrzos.org.pl/projekt1.18/download/Ekspertyza\%20 Anglia.pdf, [dostęp: 06.07.2019].

Warren-Adamson C., (red.), Family Centres and their International Role in Social Action: Social Work as Informal Education, 1 edition, 5 October 2017, Routledge.

Zych W., Europejskie kierunki w opiece kompensacyjnej, [w:] System opieki kompensacyjnej w zjednoczonej Europie, red. S. Badora, D. Marzec, Oficyna Wydawnicza Impuls, Kraków 2002. 